\title{
Comparative Analysis of Bookkeeping at Sole Proprietorship and Partnership Small and Medium Enterprises: Study on Culinary Sector in Greenville, Jakarta
}

\author{
Fionna Griseldis Lisjanto \\ Institut Teknologi Bandung \\ Jakarta, Indonesia \\ fgriseldis@gmail.com \\ Asep Darmansyah \\ Institut Teknologi Bandung \\ Bandung, Indoneisa \\ asep.darmansyah@sbm-itb.ac.id \\ DOI: 10.31364/SCIRJ/v6.i6.2018.P0618533 \\ http://dx.doi.org/10.31364/SCIRJ/v6.i6.2018.P0618533
}

\begin{abstract}
$A$ bstract- SMEs (Small and Medium Enterprises) in Indonesia have a great impact for the nation's economic development. However, many SMEs failed in their business because lack of managing bookkeeping in the business. Many has stated that most of the owners/ managers do not have accounting knowledge nor to realize the importance of bookkeeping. Thus, this study aims to examine further whether there any differences of bookkeeping in sole proprietorship and partnership SMEs, since both are non-legal entity and most SMEs are in the form of it. This study also seeks for an answer on which from the two form of ownership has better quality in bookkeeping. The research was descriptive in nature involving quantitative methods, which was administered through questionnaires. The population is culinary SMEs in Greenville, Jakarta with total sample encompassed of 44 respondents-21 sole proprietorship and 23 partnership SMEs using purposive sampling. Data analysis was carried out using charts, percentages, and independent-sample $t$ test. Findings from independent $t$-test result reveal that there are significant differences between sole proprietorship and partnership SMEs in terms of their bookkeeping.
\end{abstract}

Index Terms - bookkeeping, record keeping, small and medium enterprises, sole proprietorship, partnership

\section{INTRODUCTION}

The government is paying close attention on the development of Indonesia's Small and Medium Enterprises (SMEs) as they are affecting the most of Indonesia's economic growth. It grows and becomes the backbone of Indonesia's economy since they make up to $99.9 \%$ of the total business units and contributed to $60.6 \%$ of Indonesia's Gross Domestic Product (GDP) in 2016 (Indrawati, 2016). The contribution of SMEs towards GDP has grown fast over the last few years, as the contribution amounted risen to $60.6 \%$ of total GDP in 2016 from $57.8 \%$ in 2011. It also has an impact to the unemployment rate as they absorb more in labor forces. It provides job opportunities for the unemployed to around $97 \%$ of the total jobs (Roeslani, 2016). Indonesia's president, Joko Widodo (2016), declared that SMEs in Indonesia have high endurance in keeping their sustainability in country's economy even when the global crisis happen. Therefore, to provide economic sustainability, the role of SMEs is really important.

Based on data from the Ministry of Cooperatives and Micro, Small, and Medium Enterprises, the number of SMEs in Indonesia continues to grow from year to year with the following growth:

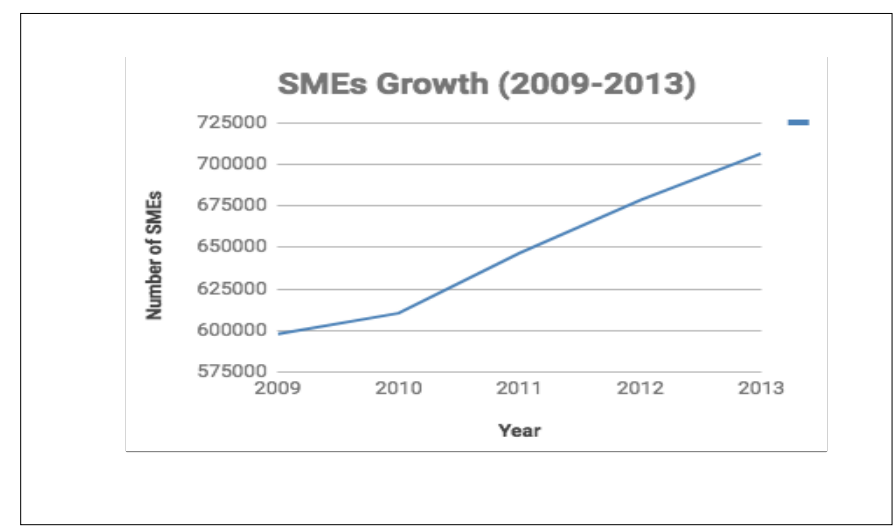

Fig. 1. Total SMEs in Indonesia, 2009-2013 
The graph above shows the growth of SMEs in Indonesia increased respectively from 2009-2013. In 2009 there are 597,979 units of SMEs, 610,405 units in 2010 , continues by in 646,475 units in 2011 , in 2012 there are 678,415 units, and in 2013 there are 706,328 units.

Considering the presence of SMEs are really vital for Indonesia's economic growth and sustainability then it must be necessary for them to survives and operates well in their business to give more contribution towards Indonesia's economic development. According to Zimmerer and Scarborough (2006), the success of small businesses reckons on how well its capability in managing good financial control. To have adequate financial control, it needs financial information to take a look on how is the financial condition of the business itself. Financial information can be obtained from financial report, which was arranged from the gathered financial data. Under that circumstances, have a good financial data can lead to better financial control. Financial data was gathered through a process called bookkeeping or record keeping. It is a systematic recording and organizing of financial transactions in a company. It ensures that records of the individual financial transactions are correct, up-to-date, and comprehensive. Bookkeeping as the foundation of setting up financial report can help a company in planning their business. It is the same with as it called "budgeting", forecasting the future and set projections and goals for the business.

Many businesses, especially the small scale one, think that bookkeeping is not really important and not worth the time (Germaain, 2010). One of the managers of small business clinics and cooperatives of the Indonesian Institute of Accountants (IAI) also stated that small entrepreneurs do not have accounting knowledge and many of them have not understood the importance of recording and bookkeeping for business sustainability. Limitation of accounting knowledge is also the cause of SMEs in Zimbabwe did not have proper accounting records, which was disclosed by Maseko and Manyani (2011) in their research. Small entrepreneurs see that the accounting process is less important to implement (Pinasti, 2007). Puspitaningtyas (2015) stated that most SMEs in Banyuwangi, Indonesia, actually have knowledge about accounting and finance. However, SMEs still make complexity as an excuse to not doing the accounting records, they assume the complexity is not worth the scale of its business, which are still relatively small. Many SMEs do not have the capacity to afford the complexity of an in depth accounting system. This has therefore, accounted for, the existence of single entries in their books and in some instances incomplete records (Onaolapo et al., $2011 \&$ Wood, 1979).

Although many SMEs still considering bookkeeping is not an important matter, it cannot be denied that bookkeeping has great significance value for a business. Based on Law Number 9 of 1995 and the Law Taxation No. 2 Year 2007 on SME and Cooperative Development, the government has affirmed the importance of recording and organizing accounting information on SMEs. With sufficient accounting knowledge, then the owner of SMEs can meet the requirements in filing credit in the form of financial statements, evaluating performance, knowing the financial position, calculating taxes, and other benefits (Warsono, 2010). Dermansyah and Hamidah (2017) stated in their research that it is important as the owners/ managers of a business to understand the basic knowledge of accounting to judging their business performance. While Pinasti (2007), seen information accounting has a very important influence on achievement business success, including small business. It is also important to useful in eliminating the doubt when making financial decision (Boateng, 2015). Moreover information accounting is also useful in order to develop various projections, such as projected needs cash in the future, control costs, measure and improve productivity and support for the production process (Johnson \& Kaplan, 1987).

Even though many stated that SMEs have not done their bookkeeping properly, it cannot be denied that there might be some of them who did it properly, because the way a business do their dayto-day activities, including doing their bookkeeping process might be different from one another. Legal ownership of a business can affect the characteristic of a business. Choosing legal form of ownership is actually a really important matter for a business since it can shape up the way a business should perform. According to (Nurhalim, 2013), there are two types of business entities in Indonesia, legal 
entity, and non-legal entity. The difference between those two is basically there is no separation of ownership in non-legal entity, which means that the owner and business are treated as the same entity. Sole proprietorship and partnership form of business are non-legal entities since there is no legal distinction between the business as an economic unit and the owner. Most of small service-types businesses retail store are in these types of ownership. While, corporation is a business organized a separate legal entity under corporation law and having ownership divided into transferable shares. This type of ownership mostly used in big companies. Small businesses often take the form of sole proprietorship or partnership since it is easier and not too many legal requirements needed.

Since different types of legal ownership have their own characteristics, then the way each of them do record keeping for their business might be different too. Therefore, this study aims to examine further the bookkeeping quality in non-legal entities since most SMEs in Indonesia are in the form of sole proprietorship and partnership with the problem carried on in this research is lack of bookkeeping in most SMEs. The study wants to examine whether there are any differences of bookkeeping quality in sole proprietorship and partnership small and medium enterprises since most SMEs in the form of sole proprietorship and partnership. This study also seeks for an answer on which from the two types has better bookkeeping quality if there are any differences between them.

\section{THEORETICAL FOUNDATION}

\section{A. Small and Medium Enterprises Categorization}

There are great diversity in the definition and classification of small firms across institutions and countries. The categorization of Small Medium Enterprises (SMEs) might be different from one country and another since the characteristics of each country is also different (Turan and Urkmez, 2010). The most common practice used to classified SMEs by ranking its number of employees. But, other variables like net assets, sales, and investment levels are also sometimes used. Below are the definitions from several sources used to categorized SMEs in Indonesia:

1) Ministry of SMEs and Cooperatives and Bank Indonesia.
The data follow the definition set out in 2008 Law. Micro firms can be categorized as enterprises with net assets less than IDR 50 million (land and building excluded) or enterprises which have less than IDR 300 million total annual sales. Small firms are enterprises with net assets from IDR 50 million to IDR 500 million (land and building excluded) or with total annual sales from IDR 300 million to IDR 2.5 billion. Medium-sized firms are those with net assets from IDR 500 million to IDR 10 billion or with total annual sales from IDR 2.5 billion to IDR 50 billion.

\section{2) World Bank Enterprise Survey.}

The categorization divides the business upon number of employees: Small-sized enterprises are those who employed 5-19 employees while medium enterprises employed 20-99 employees. The survey covers only the firms with more than 5 employees.

\section{3) International Finance Corporation}

These sources have various definitions among countries. For Indonesia, data was taken from the Ministry of SMEs and Cooperatives and follow the definition in the 2008 Law.

\section{B. Bookkeeping}

\section{1) Definition of Bookkeeping}

Bookkeeping is the process of recording all the information regarding the transactions and financial activities of a business. Based on Law Number 28 Year 2007 Article 1 (29) about General Provision and Taxation Procedure, bookkeeping is "a process of recording that is done regularly to collect data and financial information covering assets, liabilities, capital, income and expenses, as well as the total cost and delivery of goods or services, which is closed by preparing financial statements in the form of balance sheet and income statement for the period of the said year." Bookkeeping is the beginning stage of the company's finance and acts as a base for all financial activities. Bookkeeping means to write down all the money that comes to the business and all the money, which goes out of the business. Bookkeeping is clearly essential to good administrative decision-making, consistency and fairness, impartiality, continuous learning and improvement, and effective risk management (Tacy, 2004). While, Epstein (2006: 12) stated that keeping the books is all about creating an accurate paper trail. An accurate paper trail is the only way to track 
the financial successes and review the financial failures.

\section{2) Good Bookkeeping}

Bookkeeping as an important part of a business has to be done properly. Irwin (1993) described proper bookkeeping procedure as one of the ways through which an organization can keep track of its financial activities in order to ensure proper financial discipline. In order to make a business keep on thriving-not just surviving, it need to do proper bookkeeping to support their financial activities. Many sources have explained the definitions of good bookkeeping. Several points have been made, which have been gathered through and categorized from different sources about good bookkeeping, which are:

\section{a) Have the right system}

According to Bryant (2017), in doing bookkeeping, it is important to create a system that best meets with the business needs and one that the business will actually use. Considering what system suits with the business play a huge part for a better bookkeeping process and results. There are several options that a business could choose, ranging simple do-it-yourself manually packages to more detailed and involved software that does more work but more accurate.

\section{- Cash and accrual systems}

Smith (2017) stated that there are two types of method that a business can choose in order to create a books record for small businesses. The first one is cash-basis accounting, which is the simpler method and many small businesses use this method. It is easier to use and maintain because this method is pretty straightforward. How this method works is to record the book entries only when cash is collected or disbursed in the business. It is a simple accounting method that makes intuitive sense. While accrual basis accounting- the second method which are the complete opposite of the cash method and more complex since the business needs to record any transaction when incomes is earned and expenses are recognized, regardless of when the money is actually received. According to Cameron (2016) and Smith (2017), cash basis method is basically for small, nonmanufacturing business and as the business grew larger, the IRS (Internal Revenue Service) expects them to switch to accrual basis method. If the business must keep an inventory of merchandise to sell to consumers and if the business offers credit payment to customer, the IRS (Internal Revenue Service) requires using accrual method. But, some small businesses also can choose the hybrid method of accounting, where in they use accrual accounting or inventory and the cash method for their income and expenses.

\section{-Manual and computerized bookkeeping system}

According to Kumar (2013), there are two system can be used to record the bookkeeping, which are manual bookkeeping system and computerized bookkeeping system. Manual bookkeeping system, as the way it called is done manually by either using actual paper journal and ledger sheets or by creating the sheets in a computer program such as Excel. It is considered manual because each transactions is entered into the system individually. However, according to Dumbrava (2016), manual bookkeeping also has its own benefits. Businesses who use this kind of system can easily review all the ledgers and make simple changes anytime. Using this system also can make the business save more money by not spending it on new equipment or even software. While, computerized bookkeeping system is basically doing the bookkeeping process by using accounting software. Technically, accountants or whomever it is in charged to do the record process, entering the financial data into the accounting program, and the software will do the rest in working on the information. This system definitely provide more benefits than the manual ones, allowing for more accurate calculations, diminishing the possibility of human error, in less time Among all of the advantages, it still have some disadvantages, such as vulnerable to security breaches, susceptible to malfunction during power outages and more expensive.

\section{b) Keep source of documents of all business transaction}

According to Madytianos (2016), keeping receipts is one of many factors of great bookkeeping. Source of document is the beginning of the entire business record keeping process. The detailed documents, such as invoice or receipts, must be kept in order to effectively keeping the books. The way on how to keep the receipts may also different in every business. Some people would like to just keep a small notebook or put the receipt in a shoebox, more conservative way. The others 
might more likely to use application in keeping the records, in a more modern way.

\section{c) Bookkeeping process}

\section{-Have a schedulel timing of the entry}

Good bookkeeping should be able to keep track of their day-to-day transactions and have a preliminary general ledger ready for their accountant (Bryant, 2017). It is best if the business can set aside a regular time to manage the records - this could be first thing in the morning or at the end of the day. Little and often is a good approach and makes it easier to stay up-to-date because it can let the business look at the opportunities and if they leave it too late then there is more possibilities that they will miss it. As Hock (2017) stated in his article, consistency is the most important principle of bookkeeping. The process of doing the entry can be done when there is new transaction occur or once a day, but of course it will be better if the recording process was done when there is transaction happening, to decreasing the possibility of making mistake when doing the posting to general ledger.

\section{-Using professional help}

Business owners have so many things to handle that pulled them in a dozen different directions. Outsourcing the job to somebody who can do quicker and better job is much smarter than trying to tackle it by yourself But on condition that do not entirely "hands-off" (Chu, 2017). Also, have someone more professional, in this case might be a bookkeeper or accountant, can assure the business to have more up-to-date and accurate records.

\section{-Single entry and double entry system}

There are two common systems that usually used in doing bookkeeping, which are single entry system and double entry system according to Peavler (2018). Single entry system is the most simple system and basically used in a small businesses with a very little or low volume of activity. Also, it only record transaction with one account. It does not track accounts like inventory, accounts payable, and accounts receivable. However, the simplicity of this system is prone to error and incompleteness because it is lacked of detailed recording information. While, double entry system is a bookkeeping system refers to a set of rules to record the financial transaction in two separate books, as a credit in one and debit in the other, which means for every transaction there is something received (debit) and something given up (credit). Each account has two columns and that each transaction is located in two accounts. It is more complex than the single entry system but more detailed and accurate for financial information usage.

\section{-Keep business transaction separate from private transaction}

According to Madytianos (2016) and Hock (2017), it is important to keep private transaction separate from business transaction.

\section{-Cover asset, liabilities, income, and expenses}

Referring to Article 28 paragraph [1] and paragraph [2] Law Number 28 year 2007 about General Provision and Taxation Procedure, it explained on who is obliged to do the bookkeeping which are individual Taxpayer conducting business activity or self-employment and statuary body Taxpayer in Indonesia. And in paragraph [7], it is stated, "the bookkeeping shall at least consist of records of assets, liabilities, capital, income and expenses, and sales and purchases so that the taxable amount can be calculated". Hock (2017) also stated that it is important to define a chart account, which is a list of transaction categories. There are 5 groups of transaction categories, which are: assets, liabilities, equities, income, and expenses.

\section{d) Result of Bookkeeping}

Doing bookkeeping can help businesses to plan ahead and allowing them to plan for purchases and other miscellaneous cost which makes it easier to make forecast for the business' needs. The bookkeeping can be considered as good enough if it can help the managers/ owners to make decision for

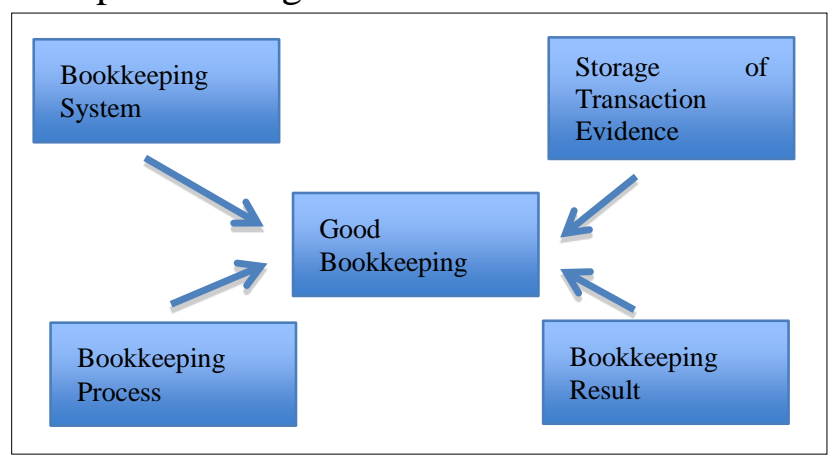

the sake of the business, as purchasing raw material or deciding to take loan from the bank. If the information gained bookkeeping result can be used and helpful for several users such as internal and external users-which already explained at the point above, then the bookkeeping itself is good enough, 
which the business can continue doing the process. Making financial report, such as income statement, balance sheet, and cash flow needed the information gained from bookkeeping result. Thus, if the business can make reliable financial report then the bookkeeping itself is reliable.

\section{3) Good Bookkeeping Framework}

According to several resources, which have been mentioned before, there are four basic indicators to measure bookkeeping quality. The indicators for the measurement are: the system used for doing bookkeeping, the storage of transaction's evidence, the process of doing bookkeeping, and the usage of bookkeeping's result.

\section{Fig. 2. Good Bookkeeping Framework}

\section{Sole Proprietorship and Partnership Form of Ownership}

There are 2 types of business entities in Indonesia, legal entity and non-legal entity (Nurhalim, 2013). The difference is there is no separation of ownership in non-legal entity. No separation of ownership means that the owner have full responsibility to pay by him/ herself if there is a loan even if him/ her need to go through their private money. Legal entity status of the SMEs is important since it adds creditworthiness of the SMEs. Majority of the SMEs in Indonesia nowadays are still in the non-legal entity form. The example of non-legal entities is sole proprietorship and partnership, which the details are explained below:

\section{1) Sole Proprietorship}

It is the most basic and common form of ownership which is a company owned by one person. All individual proprietors have title to all business assets and the responsibility of all liabilities. The owner will get all the profit for him/herself but also assume all losses, bear all risks, and pay all debts. The owner is free from interference by partners, shareholders, and directors. This legal entity has no legal distinction between the owner and the business.

\section{2) Partnership}

Partnership is a form of ownership, which was owned by two or more co-workers to operate a business and agreed to share in its profits. It can be created with little formality, but because more than one person is involved, a written contract or agreement should be created. A legal agreement needs to be made to explain things clearly about the decisions will be made, profit will be shared, clashes need to be resolved, or the other crucial things to explain the relationship between two partners. Apart from it, they also must decide up front on how much time and capital each will contribute. The red tape involved in this kind of business type is not complicated. It has similar characteristic with sole proprietorship except for the profits and losses of the partnership are divided by in an agreed percentage by the partners.

\section{Hypothesis Development}

There has no research found about bookkeeping implementation in sole proprietorship and partnership. However, Onugu (2005) stated in his research that SME in the form of partnership has better performance than in the form of sole proprietorship and both has significant differences. Also, Singapurwoko (2012: 1425) in his findings stated that there is a significant difference in profitability between sole proprietorship and partnership SME form. Partnership SME form has better profitability than SME in sole proprietorship form. As the need of measuring business performance and the success of a business have positive relationship with bookkeeping (Chelimo and Sopia, 2014), thus it can be hypothesized as follow:

Ho: there are no differences between bookkeeping in sole proprietorship and partnership SMEs.

$\mathrm{H} 1$ : there are differences between bookkeeping in sole proprietorship and partnership SMEs.

The hypothesis is generated by analyzing research and comparing bookkeeping implementation in sole proprietorship and partnership SMEs to know if there are significance differences between them using comparison methods.

\section{MethodOLOGY}

\section{A.Research Design}

To answer the research questions and reach the objectives of this research, which was generated from the problem found about lack of bookkeeping in SMEs, the study is designed to identify the 
differences between bookkeeping quality in sole proprietorship SMEs and partnership SMEs. This study uses descriptive study as research design and adopted a survey approach. Arikunto (2006) confirmed that descriptive research is not intended to test a particular hypothesis but describes what it is about a variable, a symptom, or a state. The data used by the authors in this study is the primary data. Primary data in this research is the result of questionnaire to the owner or store manager in SMEs.

\section{B. Populations and Sampling Method}

Population is a collection of individuals or research objects that have the qualities and characteristics specified by the research to be studied and then drawn its conclusions (Sugiyono, 1999). Population of this study is culinary sole proprietorship and partnership SMEs in Greenville, Jakarta Barat. The reason on choosing the population is because there are more convenient for researcher to conduct the research in that area. Unfortunately, the number of culinary SMEs in Greenville, Jakarta Barat is not available and it is possible and inaccurate if the researcher should calculate the total of SMEs in that location. So, in this research the population size are not available

The research design requires this research to test two groups of population: the sole proprietorship culinary SMEs and the partnership culinary SMEs. The sampling method used was purposive sampling method. Sugiyono (2001: 61) stated that purposive sampling is a technique of determining samples with certain considerations. Selected characteristics on this study are SMEs which in the form of sole proprietorship and partnership with 5-19 or 20-99 number of employees, to determine whether the business is categorized in small or medium enterprises. The categorization of SMEs follows the World Bank Indonesia Survey. Because the population sizes are not available in this research, the samples that will be conducted are 30 , which are the minimum samples according to Supranto, 2009. In total, this research obtains 44 respondents, 21 sole proprietorship SMEs and 23 partnership SMEs.

\section{C.Data Collection}

\section{1) Questionnaire}

A self-administered printed questionnaire consists of close-ended questions and like rt-scale was used in gathering the data. Self-administered questionnaire means that the respondents answer the questions by completing the questionnaire themselves. The researcher personally distributed the questionnaire and have the respondents answered it freely without any personal questions. Participants in this survey were voluntary and the respondents were assured of confidentiality.

\section{Research Variables and Measurement}

This research is about to find whether there are any differences in bookkeeping quality between sole proprietorship and partnership SMEs. Thus, the variable in this research is bookkeeping quality. In order to assess the quality of bookkeeping, this research depends on past literature about good bookkeeping, which has already summarized into four main dimensions: bookkeeping system, storage of transaction evidence, bookkeeping process, and the result of bookkeeping.

\section{E. Data Analysis}

\section{1) Pilot testing}

The questionnaire was made by the author and has not been tested before. So, in order to get a valid and reliable result, testing the validity and reliability is crucial. Cronbrach's aplha method was used to identify the reliability of the questionnaire, while Pearson Correlation was used to identify the validity of the questionnaire.

\section{2) Method of Successive Interval (MSI)}

The method used to analyse the data in this research are independent-t test, which require an interval data for the dependent variables. However, the result that was gathered through questionnaire was in the form of nominal data. Thus, this research needed Method of Successive Interval (MSI) to transform nominal data into interval data.

\section{3) SPSS}

SPSS Statistics software was used to analyze the quantitative data. This research used a few statistical tools including Cronbach's aplha, Pearson Correlation, Shapiro-Wilk's test, Levene's F test, and independent t-test. Cronbach's aplha was used to test the reliability and Pearson Correlation to test the validity of the questionnaire. To evaluate whether the mean of two independent groups are significantly different from each other, which are bookkeeping in sole proprietorship culinary SMEs 
and bookkeeping in partnership culinary SMEs, this research used independent-samples $t$ test and SPSS was used to help analyse the data. There are several assumptions needed to be tested if independent $t$ test was used, which will be tested using SPSS, and there are:

1. The assumption of normality, using ShapiroWilk's test

2. The assumption of homogeneity of variance was used to make sure there is no variances approximately equal across groups, using Levene's F test.

\section{DATA ANALYSIS}

\section{A. Validity and Reliability}

In pilot testing, validity and reliability was conducted for the questionnaire to measure if the questionnaire are valid and reliable enough to be use in this research.

\section{1) Validity}

According to Hair et al (1998), validity is "extent to which a measure or set of measures correctly represents the concept of study- the degree to which it is free from any systematic or nonrandom error. Validity is concerned with how well the concept is defined by the measure(s)." Validity in this pilot testing is calculated by using Microsoft Excel software. The result is valid if the calculated$\mathrm{t}>\mathrm{t}$ from table and all the item questions are valid and can be use in this study.

\section{2) Reliability}

According to Hair et al (1998), reliability is "extent to which a variable or set of variables is consistent in what it is intended to measure." The questionnaire on this study calculated reliability by using SPSS software with Cronbach's aplha method. The result will be stated as reliable if the value of Cronbach's aplha value $>0.60$. Based on the results of reliability testing, all the research variables have Cronbach's Alpha value greater than 0.60. So the questionnaire used in this study is reliable.

\section{B. Respondent's Profile}

This research is about comparing two populations which are sole proprietorship culinary SMEs and partnership culinary SMEs. Thus, this further analysis will be done by drawing a comparison between them.

TABLE I. RESPONDENT's PROFILE

\begin{tabular}{|c|c|c|c|}
\hline & & $\begin{array}{c}\text { Sole } \\
\text { Proprietorship }\end{array}$ & Partnership \\
\hline \multirow[t]{2}{*}{ Gender } & Male & $52 \%$ & $52 \%$ \\
\hline & Female & $48 \%$ & $48 \%$ \\
\hline \multirow[t]{5}{*}{ Age } & $<20$ & 0 & $5 \%$ \\
\hline & $20-35$ & $67 \%$ & $78 \%$ \\
\hline & $36-50$ & $14 \%$ & $13 \%$ \\
\hline & $51-65$ & $14 \%$ & $4 \%$ \\
\hline & $>65$ & $5 \%$ & 0 \\
\hline \multirow[t]{4}{*}{ Education } & High school & $33 \%$ & $4 \%$ \\
\hline & Diploma & $9 \%$ & $4 \%$ \\
\hline & Bachelor degree & $48 \%$ & $83 \%$ \\
\hline & Post graduate & $10 \%$ & $9 \%$ \\
\hline \multirow{2}{*}{$\begin{array}{l}\text { Number } \\
\text { employees }\end{array}$} & $5-19$ & $81 \%$ & $83 \%$ \\
\hline & $20-99$ & $19 \%$ & $17 \%$ \\
\hline \multirow[t]{4}{*}{ Age of Business } & $<1$ & $19 \%$ & $56 \%$ \\
\hline & $1-5$ & $53 \%$ & $35 \%$ \\
\hline & $6-10$ & $14 \%$ & $9 \%$ \\
\hline & $>10$ & $14 \%$ & 0 \\
\hline
\end{tabular}

The respondents' gender categories both in sole proprietorship and partnership group are represented by $48 \%$ woman and $52 \%$ man. The majority of the respondents were man, which has a percentage of more $4 \%$.

The respondents' age categories in sole proprietorship SMEs are $67 \%$ in the categories of $20-35$ years, $14 \%$ in $36-50$ years group, $14 \%$ in $51-$ 65 years group, and $5 \%$ in $>65$ years group. While for the respondents in partnership SMEs are $78 \%$ in the categories of $20-35$ years, $13 \%$ in $36-50$ years, $4 \%$ in 51-65 years, and 5\% in $<20$ years. Both of sole proprietorship and partnership SMEs have the majority of respondent in their 20-35 years.

The respondents' education background in sole proprietorship SMEs are $48 \%$ have bachelor degree, $33 \%$ have high school degree, $10 \%$ have post graduate degree, and 9\% have diploma degree. While for respondents in partnership SMEs are 83\% have bachelor degree, $9 \%$ have postgraduate degree, $4 \%$ hace high school degree, and $4 \%$ have diploma degree. Both of sole proprietorship and partnership SMEs' respondents are mostly have bachelor degree in their education background.

The respondent's number of employees in sole proprietorship SMEs is $81 \%$ have 5-19 employees and $19 \%$ have 20-99 employees. While in partnership SMEs, 83\% have 5-19 employees, and $17 \%$ have $20-99$ employees. So, it indicates that the 
majority of respondents were small-sized enterprises.

The respondents' age of business in sole proprietorship SMEs are 53\% in 1-5 years group, $19 \%$ in $<1$ year group, 14\% in 6-10 years group, and $14 \%$ in $>10$ years group. While in partnership SMEs, $56 \%$ are in <1-year group, $35 \%$ in $1-5$ years

\begin{tabular}{|c|c|c|c|c|}
\hline \multirow[t]{2}{*}{ Answer } & \multicolumn{2}{|c|}{$\begin{array}{c}\text { Sole Proprietorship } \\
(\mathbf{N}=21)\end{array}$} & \multicolumn{2}{|c|}{$\begin{array}{c}\text { Partnership } \\
(\mathrm{N}=23)\end{array}$} \\
\hline & Total & $\%$ & Total & $\%$ \\
\hline Never & 2 & 10 & 0 & 0 \\
\hline Sometimes & 8 & 38 & 7 & 30 \\
\hline Always & 11 & 52 & 16 & 70 \\
\hline TOTAL & 21 & 100 & 23 & 100 \\
\hline
\end{tabular}

group, and 9\% in 6-10 years group. The majority in sole proprietorship SMEs is respondents in 1-5 year's age of business and the majority in partnership SMEs are respondents in <1-year age of business.

\section{C.Descriptive Statistics}

\section{1) Dimension I. Bookkeeping System}

TABLE II. QUESTION 1: WHAT KIND OF TRANSACTION DO YOU RECORD IN THE BOOKS OF THE COMPANY?

\begin{tabular}{|c|c|c|c|c|}
\hline \multirow[t]{2}{*}{ Answer } & \multicolumn{2}{|c|}{$\begin{array}{l}\text { Sole Proprietorship } \\
(\mathrm{N}=21)\end{array}$} & \multicolumn{2}{|c|}{$\begin{array}{l}\text { Partnership } \\
(\mathrm{N}=23)\end{array}$} \\
\hline & Total & $\%$ & Total & $\%$ \\
\hline Just cash & 16 & 76 & 1 & 4 \\
\hline $\begin{array}{l}\text { All accounts } \\
\text { (sometimes) }\end{array}$ & 1 & 5 & 3 & 13 \\
\hline $\begin{array}{l}\text { All accounts } \\
\text { (always) }\end{array}$ & 4 & 19 & 19 & 83 \\
\hline TOTAL & 21 & 100 & 23 & 100 \\
\hline
\end{tabular}

Both in sole proprietorship and partnership SMEs, most of them stated that they always keep cash-in receipts in their business, with $52 \%$ and $70 \%$ for sole proprietorship and partnership SMEs, respectively.

TABLE III. QUESTION 2: HOW DO YOU RECORD YOUR BUSINESS' TRANSACTION?

\begin{tabular}{|c|c|c|c|c|}
\hline \multirow[t]{2}{*}{ Answer } & \multicolumn{2}{|c|}{$\begin{array}{c}\text { Sole Proprietorship } \\
(\mathrm{N}=21)\end{array}$} & \multicolumn{2}{|c|}{$\begin{array}{c}\text { Partnership } \\
(\mathbf{N}=23)\end{array}$} \\
\hline & Total & $\%$ & Total & $\%$ \\
\hline Manual & 8 & 38 & 3 & 13 \\
\hline $\begin{array}{l}\text { Computerized } \\
\text { without accounting } \\
\text { software }\end{array}$ & 9 & 43 & 12 & 52 \\
\hline Computerized with & 4 & 19 & 8 & 35 \\
\hline
\end{tabular}

\begin{tabular}{|l|l|l|l|l|}
\hline $\begin{array}{l}\text { accounting } \\
\text { software }\end{array}$ & & & & \\
\hline TOTAL & 21 & 100 & 23 & 100 \\
\hline
\end{tabular}

Most of sole proprietorship and partnership SMEs already did their record keeping in a computerized system but without accounting software, which represented by $43 \%$ and $52 \%$ for sole proprietorship and partnership SMEs, respectively

\section{2) Dimension II. Storage of transaction evidence}

TABLE IV. QUESTION 3: DO YOU KEEP CASH IN RECEIPTS (IN THE FORM OF NOTES OR RECEIPTS)?

Both in sole proprietorship and partnership SMEs, most of them stated that they always keep cash-in receipts in their business, with $52 \%$ and $70 \%$ for sole proprietorship and partnership SMEs, respectively.

TABLE V. QUESTION 4: DO YOU KEEP ANY CASH OUT OF THE COMPANY (IN THE FORM OF A NOTE OR A RECEIPT)?

\begin{tabular}{|c|c|c|c|c|}
\hline \multirow{2}{*}{ Answer } & \multicolumn{2}{|c|}{$\begin{array}{c}\text { Sole Proprietorship } \\
(\mathbf{N}=21)\end{array}$} & \multicolumn{2}{|c|}{$\begin{array}{l}\text { Partnership } \\
(\mathrm{N}=23)\end{array}$} \\
\hline & Total & $\%$ & Total & $\%$ \\
\hline Never & 2 & 10 & 0 & 0 \\
\hline Sometimes & 8 & 38 & 8 & 35 \\
\hline Always & 11 & 52 & 15 & 65 \\
\hline TOTAL & 21 & 100 & 23 & 100 \\
\hline
\end{tabular}

Both in sole proprietorship and partnership SMEs, most of them stated that they always keep cash-out receipts in their business, with $52 \%$ and $65 \%$ for sole proprietorship and partnership SMEs, respectively.

TABLE VI. QUESTION 5: DO YOU KEEP A PURCHASE INVOICE (PROOF OF PURCHASE OF GOODS ON CREDIT)?

\begin{tabular}{|c|c|c|c|c|}
\hline \multirow{2}{*}{ Answer } & \multicolumn{2}{|c|}{$\begin{array}{c}\text { Sole Proprietorship } \\
(\mathbf{N}=21)\end{array}$} & \multicolumn{2}{|c|}{$\begin{array}{l}\text { Partnership } \\
(\mathrm{N}=23)\end{array}$} \\
\hline & Total & $\%$ & Total & $\%$ \\
\hline Never & 2 & 9 & 2 & 9 \\
\hline Sometimes & 9 & 43 & 6 & 26 \\
\hline Always & 10 & 48 & 15 & 65 \\
\hline TOTAL & 21 & 100 & 23 & 100 \\
\hline
\end{tabular}

Both in sole proprietorship and partnership SMEs, most of them stated that they always keep purchase invoice in their business, with $48 \%$ and $65 \%$ for sole proprietorship and partnership SMEs, respectively.

\section{3) Dimension III. Bookkeeping Process}

TABLE VII. QUESTION 6: HOW DO YOU RECORD COMPANY BOOKKEEPING? 


\begin{tabular}{|l|l|l|l|l|}
\hline \multirow{2}{*}{ Answer } & \multicolumn{2}{|c|}{$\begin{array}{c}\text { Sole Proprietorship } \\
\text { (N=21) }\end{array}$} & \multicolumn{2}{c|}{$\begin{array}{c}\text { Partnership } \\
\text { (N=23) }\end{array}$} \\
\cline { 2 - 5 } Total & \multicolumn{2}{|c|}{$\%$} & \multicolumn{2}{|c|}{ Total } \\
\hline Single entry & 12 & 57 & 6 & 26 \\
\hline $\begin{array}{l}\text { Double entry } \\
\text { (not all the } \\
\text { time) }\end{array}$ & 5 & 24 & 4 & 17 \\
\hline Double entry & 4 & 19 & 13 & 57 \\
\hline TOTAL & 21 & 100 & 23 & 100 \\
\hline
\end{tabular}

Most SMEs in sole proprietorship form of business did their bookkeeping in a single entry form, which represented by $57 \%$ of total respondents. While, in partnership SMEs, most of them already did their bookkeeping in the form of double entry bookkeeping, which represented by $57 \%$ of total respondents.

TABLE VIII. QUESTION 7: HOW LONG DO YOU NEED TO KEEP TRACK OF YOUR COMPANY'S FINANCIAL TRANSACTIONS?

\begin{tabular}{|c|c|c|c|c|}
\hline \multirow{2}{*}{ Answer } & \multicolumn{2}{|c|}{$\begin{array}{c}\text { Sole Proprietorship } \\
(\mathrm{N}=21)\end{array}$} & \multicolumn{2}{|c|}{$\begin{array}{l}\text { Partnership } \\
(\mathrm{N}=\mathbf{2 3})\end{array}$} \\
\hline & Total & $\%$ & Total & $\%$ \\
\hline $\begin{array}{ll}\begin{array}{l}\text { Several days } \\
\text { after }\end{array} & \\
\end{array}$ & 9 & 43 & 10 & 43 \\
\hline $\begin{array}{ll}\begin{array}{l}\text { Several hours } \\
\text { after }\end{array} \\
\end{array}$ & 7 & 33 & 6 & 26 \\
\hline Right away & 5 & 24 & 7 & 30 \\
\hline TOTAL & 21 & 100 & 23 & 100 \\
\hline
\end{tabular}

Both in sole proprietorship and partnership SMEs keep track on their financial transactions in several days after the transaction happening, which represented by $43 \%$ both in sole proprietorship and partnership SMEs.

TABLE IX. QUESTION 8: DO YOU REGULARLY RECORD FINANCIAL TRANSACTIONS?

\begin{tabular}{|c|c|c|c|c|}
\hline \multirow[t]{2}{*}{ Answer } & \multicolumn{2}{|c|}{$\begin{array}{c}\text { Sole Proprietorship } \\
(\mathbf{N}=21)\end{array}$} & \multicolumn{2}{|c|}{$\begin{array}{l}\text { Partnership } \\
(\mathrm{N}=\mathbf{2 3})\end{array}$} \\
\hline & Total & $\%$ & Total & $\%$ \\
\hline No & 2 & 10 & 0 & 0 \\
\hline Sometimes & 5 & 24 & 7 & 30 \\
\hline Yes & 14 & 67 & 16 & 70 \\
\hline TOTAL & 21 & 100 & 23 & 100 \\
\hline
\end{tabular}

Both sole proprietorship and partnership SMEs stated that they already did bookkeeping regularly in their business. $67 \%$ and $70 \%$ of total respondent in sole proprietorship and partnership SMEs represents it, respectively.

TABLE X. QUESTION 9: DO YOU SEPARATE FINANCIAL AND PERSONAL REPORTING?

\begin{tabular}{|c|c|c|c|c|}
\hline \multirow{3}{*}{ Answer } & \multicolumn{2}{|c|}{$\begin{array}{c}\text { Sole Proprietorship } \\
(\mathbf{N}=21)\end{array}$} & \multicolumn{2}{c|}{$\begin{array}{c}\text { Partnership } \\
(\mathbf{N}=23)\end{array}$} \\
\cline { 2 - 4 } & Total & $\%$ & Total & $\%$ \\
\hline
\end{tabular}

\begin{tabular}{|l|l|l|l|l|}
\hline Never & 2 & 10 & 1 & 4 \\
\hline Sometimes & 2 & 10 & 2 & 9 \\
\hline Always & 17 & 81 & 20 & 87 \\
\hline TOTAL & 21 & 100 & 23 & 100 \\
\hline
\end{tabular}

Both sole proprietorship and partnership SMEs stated that they always separate financial reporting and financial reporting in their business. $81 \%$ and $87 \%$ of total respondent in sole proprietorship and partnership SMEs represents it, respectively.

TABLE XI. QUESTION 10: WHAT ARE YOUR ACCOUNTING RECORDS?

\begin{tabular}{|l|l|l|l|l|}
\hline \multirow{2}{*}{ Answer } & \multicolumn{2}{c|}{$\begin{array}{c}\text { Sole } \\
\text { Proprietorship } \\
\text { (N=21) }\end{array}$} & \multicolumn{2}{c|}{$\begin{array}{c}\text { Partnership } \\
\text { (N=23) }\end{array}$} \\
\cline { 2 - 5 } & \multicolumn{1}{|c|}{ Total } & \multicolumn{2}{c|}{ Total } & \% \\
\hline $\begin{array}{l}\text { One of these five (assets, } \\
\text { liabilities, capital, income- } \\
\text { expenses, and purchases) }\end{array}$ & 3 & 14 & 1 & 4 \\
\hline $\begin{array}{l}\text { Some of these five (assets, } \\
\text { liabilities, capital, income- } \\
\text { expenses, and purchases) }\end{array}$ & 13 & 62 & 5 & 22 \\
\hline $\begin{array}{l}\text { All of these five (assets, } \\
\text { liabilities, capital, income- } \\
\text { expenses, and purchases) }\end{array}$ & 5 & 24 & 17 & 74 \\
\hline TOTAL & 21 & 10 & 23 & 100 \\
\hline
\end{tabular}

The majority of respondent in sole proprietorship SMEs stated that they only record some of these five records (assets, liabilities, capital, income-expenses, and purchases), which represented by $62 \%$ of total respondents. While, majority of respondents in partnership SMEs stated that they keep record of all these five records (assets, liabilities, capital, incomeexpenses, and purchases), which represented by $74 \%$ of total respondents.

TABLE XII. QUESTION 11: Do YOU RECORD SALES TRANSACTION?

\begin{tabular}{|l|l|l|l|l|}
\hline \multirow{2}{*}{ Answer } & \multicolumn{2}{c|}{$\begin{array}{c}\text { Sole Proprietorship } \\
\text { (N=21) }\end{array}$} & \multicolumn{2}{c|}{$\begin{array}{c}\text { Partnership } \\
\text { (N=23) }\end{array}$} \\
\cline { 2 - 6 } & \multicolumn{1}{|c|}{ Total } & \multicolumn{1}{c|}{$\%$} & \multicolumn{1}{c|}{ Total } & \% \\
\hline Never & 1 & $5 \%$ & 1 & 4 \\
\hline Sometimes & 1 & $5 \%$ & 1 & 4 \\
\hline Always & 19 & 90 & 21 & 91 \\
\hline TOTAL & 21 & 100 & 23 & 100 \\
\hline
\end{tabular}

Both sole proprietorship and partnership SMEs stated that they always do record of sales transaction. $90 \%$ and $91 \%$ of total respondent in sole proprietorship and partnership SMEs represents it, respectively.

TABLE XIII. QUESTION 12: DO YOU RECORD PURCHASE TRANSACTION?

\begin{tabular}{|c|c|c|c|c|}
\hline \multirow{2}{*}{ Answer } & \multicolumn{2}{|c|}{$\begin{array}{c}\text { Sole Proprietorship } \\
(\mathbf{N}=21)\end{array}$} & \multicolumn{2}{|c|}{$\begin{array}{c}\text { Partnership } \\
(\mathbf{N}=23)\end{array}$} \\
\hline & Total & $\%$ & Total & $\%$ \\
\hline Never & 1 & 5 & 0 & 0 \\
\hline
\end{tabular}




\begin{tabular}{|l|l|l|l|l|}
\hline Sometimes & 3 & 14 & 2 & 9 \\
\hline Always & 17 & 81 & 21 & 91 \\
\hline TOTAL & 21 & 100 & 23 & 100 \\
\hline
\end{tabular}

Both sole proprietorship and partnership SMEs stated that they always do record of purchase transaction. $81 \%$ and $91 \%$ of total respondent in sole proprietorship and partnership SMEs represents it, respectively.

TABLE XIV. QUESTION 13: DO YOU RECORD STOCK INVENTORY TRANSCATION?

\begin{tabular}{|c|c|c|c|c|}
\hline \multirow[t]{2}{*}{ Answer } & \multicolumn{2}{|c|}{$\begin{array}{c}\text { Sole Proprietorship } \\
(\mathrm{N}=21)\end{array}$} & \multicolumn{2}{|c|}{$\begin{array}{c}\text { Partnership } \\
(\mathrm{N}=23)\end{array}$} \\
\hline & Total & $\%$ & Total & $\%$ \\
\hline Never & 5 & 24 & 1 & 4 \\
\hline Sometimes & 3 & 14 & 3 & 13 \\
\hline Always & 13 & 62 & 19 & 83 \\
\hline TOTAL & 21 & 100 & 23 & 100 \\
\hline
\end{tabular}

Both sole proprietorship and partnership SMEs stated that they always do record of stock inventory transaction. $62 \%$ and $83 \%$ of total respondent in sole proprietorship and partnership SMEs represents it, respectively.

TABLE XV. QUESTION 14: DO YOU RECORD PAYROLL TRANSACTION?

\begin{tabular}{|c|c|c|c|c|}
\hline \multirow[t]{2}{*}{ Answer } & \multicolumn{2}{|c|}{$\begin{array}{c}\text { Sole Proprietorship } \\
(\mathbf{N}=\mathbf{2 1})\end{array}$} & \multicolumn{2}{|c|}{$\begin{array}{c}\text { Partnership } \\
(\mathrm{N}=\mathbf{2 3})\end{array}$} \\
\hline & Total & $\%$ & Total & $\%$ \\
\hline Never & 4 & 19 & 0 & 0 \\
\hline Sometimes & 2 & 10 & 2 & 9 \\
\hline Always & 15 & 71 & 21 & 91 \\
\hline TOTAL & 21 & 100 & 23 & 100 \\
\hline
\end{tabular}

Both sole proprietorship and partnership SMEs stated that they always do record of payroll transaction. $71 \%$ and $91 \%$ of total respondent in sole proprietorship and partnership SMEs represents it, respectively.

TABLE XVI. QUESTION 15: DO YOU RECORD CASH IN AND CASH OUT TRANSACTION?

\begin{tabular}{|c|c|c|c|c|}
\hline \multirow[t]{2}{*}{ Answer } & \multicolumn{2}{|c|}{$\begin{array}{c}\text { Sole Proprietorship } \\
(\mathbf{N}=21)\end{array}$} & \multicolumn{2}{|c|}{$\begin{array}{c}\text { Partnership } \\
(\mathbf{N}=\mathbf{2 3})\end{array}$} \\
\hline & Total & $\%$ & Total & $\%$ \\
\hline Never & 1 & 5 & 0 & 0 \\
\hline Sometimes & 4 & 19 & 4 & 17 \\
\hline Always & 16 & 76 & 19 & 83 \\
\hline TOTAL & 21 & 100 & 23 & 100 \\
\hline
\end{tabular}

Both sole proprietorship and partnership SMEs stated that they always do record of cash in and cash out transaction. $76 \%$ and $83 \%$ of total respondent in sole proprietorship and partnership SMEs represents it, respectively.

\section{4) Dimension IV. The result of bookkeeping}

TABLE XVII. QUESTION 16: ARE THE RESULTS OF FINANCIAL RECORDS USED IN MAKING THE PURCHASE DECISION OF RAW MATERIALS?

\begin{tabular}{|c|c|c|c|c|}
\hline \multirow[t]{2}{*}{ Answer } & \multicolumn{2}{|c|}{$\begin{array}{c}\text { Sole Proprietorship } \\
(\mathbf{N}=21)\end{array}$} & \multicolumn{2}{|c|}{$\begin{array}{c}\text { Partnership } \\
(\mathbf{N}=\mathbf{2 3})\end{array}$} \\
\hline & Total & $\%$ & Total & $\%$ \\
\hline Never & 7 & 33 & 2 & 9 \\
\hline Doubt it & 2 & 10 & 4 & 17 \\
\hline Always & 12 & 57 & 17 & 74 \\
\hline TOTAL & 21 & 100 & 23 & 100 \\
\hline
\end{tabular}

Both sole proprietorship and partnership SMEs stated that they always use the results of financial records in making purchase decision of raw material in their business. $57 \%$ and $74 \%$ of total respondent in sole proprietorship and partnership SMEs represents it, respectively.

TABLE XVIII. QUESTION 17: IS THE RESULT OF FINANCIAL RECORDING USED IN DECISION MAKING TO PERFORM BANK LOAN?

\begin{tabular}{|c|c|c|c|c|}
\hline \multirow[t]{2}{*}{ Answer } & \multicolumn{2}{|c|}{$\begin{array}{c}\text { Sole Proprietorship } \\
(\mathbf{N}=21)\end{array}$} & \multicolumn{2}{|c|}{$\begin{array}{c}\text { Partnership } \\
(\mathrm{N}=\mathbf{2 3})\end{array}$} \\
\hline & Total & $\%$ & Total & $\%$ \\
\hline Never & 16 & 76 & 13 & 57 \\
\hline Doubt it & 2 & 10 & 3 & 13 \\
\hline Always & 3 & 14 & 7 & 30 \\
\hline TOTAL & 21 & 100 & 23 & 100 \\
\hline
\end{tabular}

Both sole proprietorship and partnership SMEs stated that never use the result of financial recording in making decision to perform bank loan. $76 \%$ and $57 \%$ of total respondent in sole proprietorship and partnership SMEs represents it, respectively.

TABLE XIX. QUESTION 18: WHO USES YOUR COMPANY'S FINANCIAL RECORDING REPORT?

\begin{tabular}{|c|c|c|c|c|}
\hline \multirow[t]{2}{*}{ Answer } & \multicolumn{2}{|c|}{$\begin{array}{c}\text { Sole Proprietorship } \\
(\mathbf{N}=21)\end{array}$} & \multicolumn{2}{|c|}{$\begin{array}{c}\text { Partnership } \\
(\mathrm{N}=23)\end{array}$} \\
\hline & Total & $\%$ & Total & $\%$ \\
\hline No one & 7 & 33 & 1 & 4 \\
\hline Internal parties & 13 & 62 & 17 & 74 \\
\hline $\begin{array}{l}\text { Internal and } \\
\text { external parties }\end{array}$ & 1 & 5 & 5 & 22 \\
\hline TOTAL & 21 & 100 & 23 & 100 \\
\hline
\end{tabular}

Both sole proprietorship and partnership SMEs stated the one who use company's financial recording report is the internal party. $62 \%$ and $74 \%$ of total respondent in sole proprietorship and partnership SMEs represents it, respectively.

TABLE XX. QUESTION 19: Do YOU CREATE AN INCOME STATEMENT?

\begin{tabular}{|c|c|c|c|c|}
\hline \multirow[t]{2}{*}{ Answer } & \multicolumn{2}{|c|}{$\begin{array}{c}\text { Sole Proprietorship } \\
(\mathrm{N}=21)\end{array}$} & \multicolumn{2}{|c|}{$\begin{array}{c}\text { Partnership } \\
(\mathbf{N}=\mathbf{2 3})\end{array}$} \\
\hline & Total & $\%$ & Total & $\%$ \\
\hline Never & 8 & 38 & 4 & 17 \\
\hline Sometimes & 4 & 19 & 6 & 26 \\
\hline
\end{tabular}




\begin{tabular}{|l|l|l|l|l|}
\hline Always & 9 & 43 & 13 & 57 \\
\hline TOTAL & 21 & 100 & 23 & 100 \\
\hline
\end{tabular}

Both sole proprietorship and partnership SMEs stated that they always create income statement, with $43 \%$ and $57 \%$ of total respondent in sole proprietorship and partnership SMEs, respectively.

TABLE XXI. QUESTION 20: DO YOU CREATE A CASH FLOW STATEMENT?

\begin{tabular}{|c|c|c|c|c|}
\hline \multirow{2}{*}{ Answer } & \multicolumn{2}{|c|}{$\begin{array}{c}\text { Sole Proprietorship } \\
(\mathbf{N}=\mathbf{2 1})\end{array}$} & \multicolumn{2}{|c|}{$\begin{array}{c}\text { Partnership } \\
(\mathrm{N}=23)\end{array}$} \\
\hline & Total & $\%$ & Total & $\%$ \\
\hline Never & 10 & 48 & 5 & 22 \\
\hline Sometimes & 2 & 10 & 6 & 26 \\
\hline Always & 9 & 43 & 12 & 52 \\
\hline TOTAL & 21 & 100 & 23 & 100 \\
\hline
\end{tabular}

The majority of respondent in sole proprietorship SMEs stated that they never create a cash flow statement, which represented by $48 \%$ of total respondents. While, majority of respondents in partnership SMEs stated that they always create a cash flow statement, which represented by $52 \%$ of total respondents.

TABLE XXII. QUESTION 21: Do YOU CREATE A BALANCE SHEET?

\begin{tabular}{|c|c|c|c|c|}
\hline \multirow[t]{2}{*}{ Answer } & \multicolumn{2}{|c|}{$\begin{array}{c}\text { Sole Proprietorship } \\
(\mathbf{N}=21)\end{array}$} & \multicolumn{2}{|c|}{$\begin{array}{c}\text { Partnership } \\
(\mathrm{N}=\mathbf{2 3})\end{array}$} \\
\hline & Total & $\%$ & Total & $\%$ \\
\hline Never & 13 & 62 & 7 & 30 \\
\hline Sometimes & 3 & 14 & 6 & 26 \\
\hline Always & 5 & 24 & 10 & 43 \\
\hline TOTAL & 21 & 100 & 23 & 100 \\
\hline
\end{tabular}

The majority of respondent in sole proprietorship SMEs stated that they never create a balance sheet, which represented by $62 \%$ of total respondents. While, majority of respondents in partnership SMEs stated that always create a balance sheet, which represented by $43 \%$ of total respondents.

\section{5) Overall implementation level of bookkeeping}

TABLE XXIII. OVERALL IMPLEMENTATION LEVEL OF BOOKKEEPING

\begin{tabular}{|l|l|l|l|l|}
\hline \multirow{2}{*}{ Level } & \multicolumn{2}{|c|}{ Sole proprietorship } & \multicolumn{2}{c|}{ Partnership } \\
\cline { 2 - 5 } & Total & \% & Total & \% \\
\hline Good & 204 & 46.3 & 311 & 64.4 \\
\hline Average & 106 & 24.0 & 114 & 23.6 \\
\hline Bad & 131 & 29.7 & 58 & 12.0 \\
\hline Total & 441 & 100 & 483 & 100 \\
\hline
\end{tabular}

According to the descriptive statistics analysis, this study concluded that bookkeeping quality in partnership SMEs are better than in sole proprietorship SMEs. As much as $64 \%$ of partnership companies carry out bookkeeping with "good" criteria compared to only $46 \%$ in proprietorship companies, as well as only $12 \%$ of partnership companies that implement bookkeeping in "bad" category compared to $30 \%$ of proprietorship companies. Thus, the number of companies that carry out bookkeeping is categorized better in the type of partnership than proprietorship. It can be seen from the overall table, Table 4.24, which stated that partnership SMEs has better score in the 'good' category rather than sole proprietorship SMEs. To analyse further about the differences between bookkeeping quality in sole proprietorship and partnership SMEs, this study used independent sample t-test, which explained in the section below.

\section{Assumption for independent sample t-test}

\section{1) Assumption of Normality}

Normality test is used to test whether the data used in the research are normally distributed or not. Normal data distribution is that the data follow the normal distribution curve where the data converge to mean and median. The normality test used for data in this research uses Shapiro-Wilk test, to test the two directions by comparing the probability acquired that have significant level $(\alpha)$ of $5 \%$. If the sig. value $>\alpha$ then the data can be considered to be normally distributed and id the sig. value $<\alpha$ then the data can be considered not normally distributed. The result of normality test using Shapiro-Wilk is as follow:

TABLE XXIV. Assumption TEST OF NORMALITY

\begin{tabular}{|l|l|l|l|l|}
\hline \multirow{2}{*}{ Form of ownership } & \multicolumn{4}{|c|}{ Shapiro-Wilk } \\
\cline { 2 - 5 } & \multicolumn{1}{|c|}{ Statistic } & $\boldsymbol{d}$ f & Sig. & Result \\
\hline Sole Proprietorship & 0.931 & 21 & 0.145 & Normal \\
\hline Partnership & 0.916 & 23 & 0.055 & Normal \\
\hline
\end{tabular}

Based on the table of normality above, the significance value of Shapiro Wilk for sole propietorship is 0.145 which is higher than 0.05 , indicating the data is normal, and the significance value of partnership also shows a number which greater than 0.05 , so it can be concluded that both data are distributed normally.

\section{2) Assumption of Homogeneity of Variance}

TABLE XXV. ASSUMPTION OF HOMOGENITY OF VARIANCES

\begin{tabular}{|l|lc|}
\hline \multicolumn{2}{|c|}{ Levene Statistic } & Sig. \\
\hline 0.41 & 0.840 \\
\hline
\end{tabular}


The significance value is 0.840 , which is greater than 0.05 , indicating there are no significance differences between the two groups variances, and the assumption of homogeneity of variances is met.

\section{E.Hypothesis Testing}

The two assumptions needed as the requirement to conduct independent- $t$ test has been fulfilled, the next step is to use parametric test, which is independent sample t-test. The statistic hypothesis needs to be tested are:

H0: There are no differences between bookkeeping implementation in sole proprietorship and partnership SMEs

H1: There are differences between bookkeeping implementation in sole proprietorship and partnership SMEs.

If the significance value is $<\alpha=5 \%$, the Ho is rejected, which means there are differences between bookkeeping implementation in sole proprietorship and partnership SMEs. However, if the significance value $>\alpha=5 \%$, the Ho is accepted, which means there are no differences between bookkeeping implementation in sole proprietorship and partnership SMEs.

TABLE XXVI. TABLE 4.6 INDEPENDENT T-TEST OF BOOKKEEPING BETWEEN SOLE PROPRIETORSHIP AND PARTNERSHIP

The result summary of hypothesis statistic test is as follow:

Reject $\mathrm{H} 0$ and accept $\mathrm{H} 1$, since the $\mathrm{p}$ value of Levene's test is printed as 0.002 , which is $<0.05$. So the null hypothesis was rejected and it can be concluded that the variance in bookkeeping of sole proprietorship SME is significantly different with partnership SME. While t-test for equality of means shows the negative value in this result, indicating that the mean bookkeeping level for the first group (sole proprietorship SME) is significantly lower than the mean for the second group (partnership SME). that:

Based on the results above, it can be concluded

- There is significance difference in bookkeeping quality between sole proprietorship and partnership SMEs $(\mathrm{p}<0.005)$.
- The average bookkeeping quality for partnership SMEs was about 8 times greater than sole proprietorship SMEs.

\section{CONCLUSION AND RECOMMENDATION}

This study compares the bookkeeping quality between sole proprietorship SMEs and partnership SMEs. And the result from independent sample ttest shows there is significance differences between bookkeeping quality in sole proprietorship SMEs and partnership SMEs. Also, according to the descriptive statistics, partnership SMEs has better bookkeeping quality than sole proprietorship SMEs. This study recommended for the future research to develop better measurement to indicating bookkeeping quality and expands the population and samples for better research.

\section{REFERENCES}

Boateng, Bernard Obeng. (2015). The SME Bookkeeping Gap. Retrieved June 18, 2018, from https://www.linkedin.com/pulse/sme-bookkeeping-gapbernard-obeng-boateng/

Bryant, K. T., (2017). Good Bookkeeping: How to Keep Financial Records. Retrieved March 12, 2018, from https://www.sage.com/en-gb/blog/good-bookkeeping-howto-keep-financial-records/

Chelimo, J. K., \& Sopia, I. O. (2014). Effects of Bookkeeping on Growth of Small and Medium Business Enterprises in Kabarnet Town, Baringo County, Kenya. International Journal of Science and Research, 3(12), 432-437.

\begin{tabular}{|c|c|l|l|l|l|c|}
\hline \multirow{3}{*}{ Variables } & \multicolumn{2}{|c|}{$\begin{array}{c}\text { Sole proprietorship } \\
\text { SMEs }\end{array}$} & \multicolumn{2}{|c|}{$\begin{array}{c}\text { Partnership } \\
\text { SMEs }\end{array}$} & \multirow{2}{*}{$\begin{array}{c}\text { 2-tail } \\
\text { Sig. }\end{array}$} & $\begin{array}{c}\text { Mean } \\
\text { Differe } \\
\text { nces }\end{array}$ \\
\cline { 2 - 5 } & Mean & $\begin{array}{c}\text { Standard } \\
\text { Deviation }\end{array}$ & Mean & $\begin{array}{c}\text { Standard } \\
\text { Deviation }\end{array}$ & 0.002 & $\mathbf{- 8 . 2 6 5}$ \\
\hline Bookkeeping & 49.5 & 9.0 & 57.7 & 7.8 & $\mathbf{0 . 0 0 2}$ \\
\hline
\end{tabular}

Chu, B., Berry, T., Landau, C., \& B. (2017, October 03). 7 Bookkeeping Habits Every Entrepreneur Should Adopt. Retrieved March 12, 2018, from https://articles.bplans.com/7bookkeeping-habits-every-entrepreneur-adopt/

Darmansyah, A. (2017). The Effect of Accounting Knowledge, Entrepreneurship Spirit and Capital Accessibility to Financial Performance of Footwear Creative Industries with Government Policy as Moderating Variable. Advanced Science Letters, 23(9), 8119-8126.

Dumbrava, Mihai. (2016). Manual Vs Computerized Accounting. Retrieved June 18, 2018, from http://www.simplexpayroll.com/blog/2016/02/manual-vscomputerized-accounting/

Epstein, L. (2006). Bookkeeping for dummies. John Wiley \& Sons. Enterprise Surveys (http://www.enterprisesurveys.org), The World Bank. 
Fajriah, L.R. Sri Mulyani: UMKM Bisa Jadi Penolong Saat Krisis Ekonomi. (n.d.). Retrieved March 03, 2018, from https://ekbis.sindonews.com/read/1128097/34/sri-mulyaniumkm-bisa-jadi-penolong-saat-krisis-ekonomi-1470113572

Germain, P, J. (2010). Small Business Bookkeeping. Ezinearticles.com

Hair, J. F., Black, W. C., Babin, B. J., Anderson, R. E., \& Tatham, R. L. (1998). Multivariate data analysis (Vol. 5, No. 3, pp. 207219). Upper Saddle River, NJ: Prentice hall.

Hock, Thiam. (2017). 15 Bookkeeping Tips for Singapore Small Businesses to Keep Clean Business Records. Retrieved June 14, 2018 from https://tinkertax.com/bookkeeping-tips/

Ikatan Akuntan Indonesia; Prinsip Akuntansi Indonesia 1984; Ikatan Akuntan Indonesia.

Indonesia, R. (2007). Undang-Undang Nomor 28 tahun 2007 tentang perubahan ketiga atas undang-undang nomor 6 tahun 1983 tentang ketentuan umum dan tata cara perpajakan. Sekretariat Negara. Jakarta.

Johnson, T. H., \& Kaplan, R. S. (1987). Relevance lost: the rise and fall of management accounting.

Kementrian Koperasi dan Usaha Kecil dan Menengah Republik Indonesia. (n.d.). Retrieved March 03, 2018, from http://www.depkop.go.id/berita-informasi/datainformasi/data-umkm/

Khabibi, I. (n.d.). Jokowi: UMKM Kunci Penopang Perekonomian Negara. Retrieved March 05, 2018, from https://news.detik.com/berita/3142927/jokowi-umkm-kuncipenopang-perekonomian-negara

Kumar, Vinod. (2013). Difference between Manual Accounting and Computerized Accounting. Retrieved June 14, 2018 from http://www.svtuition.org/2013/11/difference-between-manualaccounting.html

Madytianos, Pam. (2016). Six tips to great bookkeeping. Retrieved June 14, 2018 from https://www.myob.com/au/blog/6-tips-togreat-bookkeeping/

Maseko, Nelson \& Manyani, Onias. (2011). Accounting practices of SMEs in Zimbabwe: An investigative study of record keeping for performance measurement (A case study of Bindura). Journal of Accounting and Taxation. 3. 10.5897/JAT11.031

Nurhalim, Yunilla. 2013. Reforming Small and Medium Enterprises (SMEs) in Indonesia: Proposal of a New Legal Entity. Tilburg University

Onaolapo, A. A., Fasina, H. T., Opoola, N. A., \& Olatunji, A. (2011). Basic Accounting One. Ogbomosho: Johnny Printing Works.

Onugu, B.A.N. 2005. "Small Medium Enterprises in Nigeria: Problems and Prospects". Dissertation. St. Clement University.

Peavler, Rosemary. (2018). What Best: Single-Entry or Double-Entry Bookkeeping? Retrieved June 13, 2018. https://www.thebalancesmb.com/what-is-best-single-entryor-double-entry-bookkeeping-393004
Pinasti, M. (2007). Pengaruh penyelenggaraan dan penggunaan informasi akuntansi terhadap persepsi pengusaha kecil atas informasi akuntansi: suatu riset eksperimen. Jurnal Riset Akuntansi Indonesia, 10(3), 321-331.

Puspitaningtyas, Z. (2015). Pemanfaatan Informasi Akuntansi Untuk Pengambilan Keputusan Bisnis Bagi Pelaku Usaha Kecil dan Menengah.

Singapurwoko, A. (2012). Comparative Analysis Of Small Medium Enterprise Profitability Based On Its Ownership Form And Ethnicity: Study On Automotive Sector In Yogyakarta. Jurnal Aplikasi Bisnis, 12(9), 1415.

Smith, Carrie. (2017). Cash vs. Accrual Accounting: What's Best for Your Small Businesses. Retrieved June 14, 2018 from https://quickbooks.intuit.com/r/bookkeeping/cash-vs-accrual accounting-whats-best-small-business/

Sugiyono, (2008). Metode Penelitian Kuantitatif, Kualitatif dan R\&D. Bandung: Penerbit Alfabeta

Sutrisno, D. (2016, November 22). UMKM Sukses Mengurangi Pengangguran. Retrieved March 03, 2018, from http://republika.co.id/berita/koran/ekonomikoran/16/11/22/oh $\quad 1$ a8b4-umkm-sukses-mengurangipengangguran

Tacy (2004) cited by Esaete,M.(2005).Quality of record keeping and performance in small business enterprises.Makerere University, Uganda

Turan, A. H., \& Ürkmez, T. (2010). Information technology satisfaction of small and medium sized enterprises in Turkey. International Bulletin of Business Administration, 9, 43-55.

Undang-Undang Republik Indonesia Nomor 20 Tahun 2008 tentang Usaha Mikro, Kecil dan Menengah (UMKM) (Law of Republic of Indonesia Number 20 of 2008 of SMEs)

Warsono, S. dan E. Murti. 2010. Akuntansi UMKM Ternyata Mudah Dipahami dan Dipraktikkan. Yogyakarta: Asgard Chapter Winarno.

Weygant, J. J., Kimmel, P. D., \& Kieso, D. E. (2010). Financial Accounting: IFRS Edition.

Zimmerer, T. W., Scarborough, N. M., \& Wilson, D. (2005). Essentials of entrepreneurship and small business management. Upper Saddle River, NJ: Pearson/Prentice Hall 